\title{
Economic and environmental feasibility study of water hyacinth briquette in Cirata Reservoir
}

\author{
Tauny Akbari ${ }^{1 *}$ \\ ${ }^{1}$ Department of Environmental Engineering, Universitas Banten Jaya, Serang, Banten, 42117, \\ Indonesia
}

\begin{abstract}
The aim of this study was to determine the economic and environmental feasibility of water hyacinth (Eichhornia crassipes) briquette. The economic feasibility was determined by the BCR, NPV, Payback Period, and BEP value. While the environmental feasibility was determined by the potential of water hyacinth briquette to control water hyacinth in Cirata Reservoir. Briquette A1P3 (the charcoal combinations of rice husk: water hyacinth $1: 1$ and the percentage of tapioca binder $5 \%$.) was used in this research. The need of water hyacinth briquettes by a satay (tiny grilled chicken) seller and a grilled fish seller is greater than the need of charcoal and coconut shell charcoal. It shows that water hyacinth briquettes have a lower economic value than charcoal and coconut shell charcoal. A project of water hyacinth briquette processing is economically feasible with the assumption that all products sold because of the BCR value $(1.1)>1$, and the NPV value $(58,390,711)>0$, with Payback Period in 4.6 years and BEP $95,621.5 \mathrm{~kg}$ in 5 years. The use of water hyacinth briquettes by a satay and grilled fish trader at $20,949 \mathrm{~kg}$ briquettes/year has the potential to control water hyacinth in Cirata Reservoir of $0.02 \%$ per year.
\end{abstract}

\section{Introduction}

The existence of water hyacinth (Eichhornia crassipes) that covers the water surface of Cirata Reservoir leads to sustainable damages in all its dimensions (social, economic, and environmental) [1]. To overcome these problems, then the types of approach used must be based on sustainability theory [2]. Sustainable water hyacinth management is a set of processes that water hyacinth management fulfil the three-dimensional paradigm of sustainability, that is economic, social, and environment so it can be to make ends meet the needs of the present and future generations. The effort to use water hyacinth into briquette processing is expected to produce a renewable energy resource, control the growth of water hyacinth, and increase the income of the community. Those efforts are in accordance with Sustainable Development Goals (SDGs) Goal 7 (Affordable and Clean Energy : By 2030, increase substantially the share of renewable energy in the global energy mix) and Goal 12

\footnotetext{
${ }^{*}$ Corresponding author: tauny.akbari@gmail.com
} 
(Responsible Production and Consumption : By 2030, achieve the sustainable management and efficient use of natural resources) [3].

Briquette A1P3 (the charcoal combinations of rice husk: water hyacinth 1:1 and the percentage of tapioca binder 5\%.) was used in this research (Fig 1). The quality of the briquettes does not meet the SNI 01-6235-2000 standard on wood charcoal briquettes, but the burning performance was better than other briquettes because it produces less smoke, odours, and dust. It is important since a thin and odourless smoke caused by water hyacinth briquettes do not interfere with the people breathing process. These briquettes also do not produce dust so it is safe to be used in food processing [4].

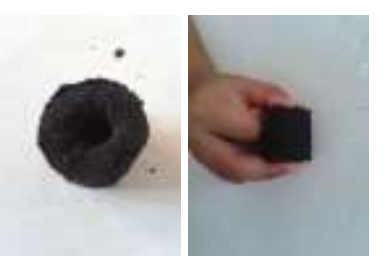

Fig 1. Water hyacinth - rice husk briquette.

\section{Methods}

Cost-plus pricing method with full costing approach was used to determine briquette selling price [5]. Economic feasibility value was measured based on Benefit-Cost Ratio (BCR), Net Present Value (NPV), Payback Period, and Break-Even Point (BEP) [6, 7]. Quantitative analysis was used to determine the environmental feasibility of water hyacinth briquettes as growth controller of water hyacinth in Cirata Reservoir.

\section{Results and discussion}

\subsection{Economic feasibility of water hyacinth briquette}

Selling price determination is the first step that must be done to analyze economic feasibility. If it is assumed that the product of briquettes per year will be used by a satay trader and grilled fish $(20,949 \mathrm{~kg} /$ year $)$, then the selling price of water hyacinth briquette is $\operatorname{Rp~6,400/kg~(Table~1).~}$

Table 1. Determination of water hyacinth briquette selling price.

\begin{tabular}{|l|l|}
\hline Markup Calculation & Price (Rp) \\
\hline Item & 174 \\
\hline Non-production cost per kg & 567 \\
\hline Profit per kg: 10\% x Rp 5,669 & 741 \\
\hline Total & 5,669 \\
\hline Production cost per kg & $\mathbf{1 3 \%}$ \\
\hline Markup percentage & \multicolumn{2}{|l|}{} \\
\hline Selling Price Calculation & Price (Rp) \\
\hline Item & 5,669 \\
\hline Production cost per kg & 743 \\
\hline Markup 13\% x Rp 5,669 Rounding off the selling price per kg & $\mathbf{6 , 4 0 0}$ \\
\hline Selling price per kg &
\end{tabular}


The selling price of water hyacinth briquette is equal to the price of wood charcoal and lower than the coconut shell charcoal selling price $(\operatorname{Rp~} 8,800 / \mathrm{kg})$. However, when it compared with the calorific value of coconut shell charcoal and charcoal wood (Table 2), water hyacinth briquettes are not economically viable to replace those two fuels, because the price of water hyacinth briquettes at the same calorific value with those fuels is higher than the price per $\mathrm{kg}$ of charcoal.

Table 2. The economic feasibility of water hyacinth briquettes as a substitute for coconut shell charcoal and wood charcoal.

\begin{tabular}{|l|l|l|}
\hline \multirow{3}{*}{ Calorific value (kcal/kg) } & Coconut shell charcoal & 4,977 \\
\cline { 2 - 3 } & Wood charcoal & 4,019 \\
\cline { 2 - 3 } & Water hyacinth briquette & 2,139 \\
\hline \multirow{3}{*}{ Selling price (IDR/kg) } & Coconut shell charcoal & 8,800 \\
\cline { 2 - 3 } & Wood charcoal & 6,400 \\
\cline { 2 - 3 } $\begin{array}{l}\text { A (calorific value of charcoal / calorific value of } \\
\text { briquette) }\end{array}$ & Water hyacinth briquette & 6,400 \\
\cline { 2 - 3 } & Coconut shell charcoal & 2.33 \\
\hline \multirow{2}{*}{ Price A (A x selling price of briquette per $\mathbf{k g})$} & Wood charcoal & 1.88 \\
\cline { 2 - 3 } & Wood charcoal & 14,891 \\
\hline
\end{tabular}

Noted: briquettes are considered economically feasible as charcoal substitutes if the price $\mathrm{A}<$ the price of one $\mathrm{kg}$ charcoal

The value of Benefit-Cost Ratio is determined during the project (Table 3). In this study, the project runs for 5 years according to the age of used equipment. Benefit value is the income of water hyacinth briquettes for 5 years (Rp 670,368,000/year), which is obtained from sales of $104,745 \mathrm{~kg}$ of water hyacinth briquettes with the selling price of Rp $6,400 / \mathrm{kg}$. Cost Value is the total of production cost and non-production cost of water hyacinth briquettes for 5 years $(\operatorname{Rp} 611,977,289)$.

Table 3. Benefit value and cost calculation of water hyacinth briquette project.

\begin{tabular}{|c|c|c|c|}
\hline & Price $(\mathrm{Rp}) /$ year & Year period & Total \\
\hline \multicolumn{4}{|l|}{ Cost } \\
\hline Production cost & $118,755,458$ & 5 & $593,777,289$ \\
\hline Non-production cost & $3,640,000$ & 5 & $18,200,000$ \\
\hline \multicolumn{3}{|l|}{ Total cost } & $611,977,289$ \\
\hline \multicolumn{4}{|l|}{ Benefit } \\
\hline Income/year & $134,073,600$ & 5 & $670,368,000$ \\
\hline
\end{tabular}

Based on the calculation of BCR and NPV values in Table 4, the water hyacinth briquette processing project is economically feasible, because the value of BCR (1.1) $>1$ and the value of NPV $(58,390,711)>0$. All costs incurred for running the project will return within 5 years with the selling products are 95,621.5 kg. After reach the payback period and BEP, all revenue received (Rp. 58,390,711, -) becomes profit for the company.

Table 4. BCR, NPV, payback period, and BEP calculation of water hyacinth briquette project.

\begin{tabular}{lll}
\hline Parameter & Value & Information \\
\hline NPV & $58,390,711$ & $>0$ \\
BCR & 1.1 & $>1$ \\
Payback Period (year) & 4.6 & - \\
BEP $(\mathrm{kg})$ & $95,621.5$ & - \\
\hline
\end{tabular}




\subsection{Environmental feasibility of water hyacinth briquette}

The growth rate of water hyacinth in a terrestrial water such as reservoir can reach 17.5 ton/ha/day [8]. The extent of water hyacinth spreads in Cirata Reservoir is estimated to reach 480 ha which spread over 4 sub-watersheds; they are Citarum-Cimeta sub-watershed, Cisokan-Cibiuk sub-watershed, Cibalagung sub-watershed, and Cilangkap sub-watershed. Thus, within a year Cirata Reservoir has the availability of wet water hyacinth of 3,066,000 tons.

The fuel needs of a satay seller and grilled fish seller is $20,949 \mathrm{~kg}$ briquettes/year. That amount requires 675.05 tons of wet water hyacinth/year, so the use of water hyacinth briquette by a satay seller and a grilled fish seller has the potential to control water hyacinth in Cirata Reservoir of $0.02 \%$ /year (Table 5). Based on the potential value, it can be seen that to utilize all water hyacinth in Cirata Reservoir it takes 5,000 satay traders and grilled fish.

Table 5. The potency of water hyacinth briquettes as water hyacinth growth controller in Cirata Reservoir.

\begin{tabular}{lllll}
\hline Sample & $\begin{array}{l}\text { Needs of water } \\
\text { hyacinth } \\
\text { briquette/year } \mathbf{( k g )}\end{array}$ & $\begin{array}{l}\text { Needs of wet } \\
\text { water } \\
\text { hyacinth/year } \\
\text { (ton) }\end{array}$ & $\begin{array}{l}\text { Availability of } \\
\text { wet water } \\
\text { hyacinth/year } \\
\text { (ton) }\end{array}$ & $\begin{array}{l}\text { The potency of } \\
\text { briquettes as water } \\
\text { hyacinth growth } \\
\text { controller (\%) }\end{array}$ \\
\hline $\begin{array}{l}\text { Water } \\
\text { hyacinth } \\
\text { briquette } \\
\text { (A1P3) }\end{array}$ & 20,949 & 675.05 & $3,066,000$ & $\mathbf{0 . 0 2 \%}$ \\
\hline
\end{tabular}

\section{Conclusion}

Water hyacinth briquettes are not economically feasible for substituting coconut shell charcoal and wood charcoal since the price of water hyacinth briquettes at the same calorific value with both fuels is higher than the price per $\mathrm{kg}$ of coconut shell charcoal and wood charcoal. However, the project of water hyacinth briquette is economically feasible due to the value of BCR (1.1)> 1 and NPV value $(58,390,711)>0$, with Payback Period 4.6 years and BEP $95,621.5 \mathrm{~kg}$ for 5 years. The use of water hyacinth briquette by a satay seller and grilled fish seller of $20,949 \mathrm{~kg}$ briquettes/year has the potential to control water hyacinth in Cirata Reservoir by $0.02 \%$ every year.

\section{References}

1. A.M. Villamagna and B.R. Murphy, Freshwater Biology 55(2) (2010)

2. R.W. Flint and W.L. Houser, Living a Sustainable Lifestyle for Our Children's (iUniverse, USA, 2001)

3. United Nations, Transforming Our World: The 2030 Agenda For Sustainable Development (United Nations, USA, 2015)

4. T. Akbari, Utilization of Water Hyacinth in Cirata Reservoir Through Briquette Processing (2013)

5. C.T. Horngren, S.M. Datar, and M.V. Rajan. Cost Accounting, A Managerial Emphasis $14^{\text {th }}$ Edition (Pearson Prentice Hall, New Jersey, 2012)

6. D.G. Newnan, T.G. Eschenbach, and J.P. Lavelle. Engineering Economic Analysis $9^{\text {th }}$ Edition (Oxford University Press, New York, 2004) 
7. European Commission, Guide to Cost-Benefit Analysis of Invesments Projects (European Union, Belgium, 2015)

8. F. Shoeb and H.J. Singh, Kinetics Studies of Biogas Evolved from Water Hyacinth. Proceeding $2^{\text {nd }}$ International Symposium on New Technologies for Environmental Monitoring and Agro- Applications (Tekirdag/Turkey, 2000) 